DOI https://doi.org/10.30525/978-9934-26-040-7-30

\title{
ВПЛИВ COVID-19 НА РИНОК ПРАЦІ В УКРАЇНІ ТА В РЕСПУБЛІЦ ПОЛЬЩА
}

\author{
Спицька К. О. \\ юристка відділу супроводу вступної кампанії \\ Київського начіонального університету імені Тараса Шевченка \\ м. Київ, Украӥна
}

Дослідження впливу коронавірусної епідемії на ринок праці в Україні та Польщі представляє собою актуальне питання для наукового вивчення.

Пандемія може викликати гірші наслідки для світового ринку праці, ніж фінансова криза 2008-2009 років, повідомила Міжнародна організація праці. Прогнозується, що криза призведе до скорочення 25 млн робочих місць у світі. Під час фінансової кризи 2008-2009 років роботу втратили понад 22 млн осіб [1].

Економіка Польщі протягом кількох останніх років стрімко розвивалася, вимагаючи усе більше нових трудових ресурсів. Польща була чи не єдиною країною $\mathrm{CC}$, яка пройшла економічну кризу 2008 року з позитивним ВВП, а за останні п'ять років кількість трудових мігрантів з України в Польщі зросло приблизно у 5 раз - до 1,5 мільйонів осіб (за орієнтовними підрахунками). Польський ринок праці в минулі роки успішно приймав українців, не завдаючи шкоди польським працівникам, адже рівень безробіття в країні паралельно також знизився до рекордного за багато років мінімуму $-5 \%$ у жовтні 2019 року [2].

Коронакриза динамічно змінила реальність. Утім, вона не змусила українців авральними темпами від'їжджати до нашої країни. Більшість iз них усе-таки вирішили залишитися у Польщі й почекати розвитку ситуації. За даними дослідження польської компанії EWL, проведеного в середині квітня 2020 р., 85\% українських респондентів висловили бажання під час пандемії COVID-19 залишитися у Польщі [2]. Більшість із них більше лякала перспектива втрати роботи (55\%), аніж імовірність захворіти на коронавірус (18\%). Масового відтоку українців додому не спричинили погіршення або зміна умов праці в умовах кризи. Їх відчули на собі багато громадян нашої держави: 61\% 
українців стали працювати менше, а 27\% були змушені змінити сферу працевлаштування [2].

Слід зазначити, що все це відбувалося за умов, коли влада України закликала громадян залишитися вдома й шукати роботу на батьківщині. Побоюючись того, що в умовах локдауну український уряд ускладнить виїзд українців на роботу за кордон (побоювання були небезпідставними), до закликів польського прем'єра Моравецького приєдналися інші польські політики найвищого рівня. Питання приїзду українських трудових мігрантів до Польщі у форматі відеоконференції наприкінці квітня 2020 р. обговорювали президенти Володимир Зеленський i Анджей Дуда, а ще через кілька днів це було й однією з основних тем переговорів глав МЗС двох країн Дмитра Кулеби і Яцека Чапутовича.

Утім, одних закликів на вищому рівні не перешкоджати виїзду працівників за кордон, мабуть, було недостатнє. Існував і дотепер існує цілий ряд перешкод для приїзду трудових мігрантів з України в Польщу. Одна 3 них - призупинення міжнародного автобусного й залізничного сполучення, які у першому півріччі минулого року були основними для українських мігрантів, що направлялися до Польщі. Питання було у фінансах - локдаун цілковито змінив ситуацію, майже дорівнявши можливість виїзду на заробітки за кордон між Польщею й Фінляндією або Німеччиною.

Серед основних проблем для польських роботодавців у нинішніх умовах - перевезення українців до місць праці, а також необхідність 14-ти денної обсервації після перетинання кордону. У Польщі намагаються швидко вирішити ці проблеми. Зокрема, на рівні уряду РП встановлено, що іноземців, котрі будуть працювати на сезонних роботах в аграрному секторі, будуть звільняти від обов'язкового двотижневого карантину. Після нетривалих дискусій вирішено за державний рахунок проводити тестування іноземних працівників на коронавирус. Зокрема, улітку 2020 р. міністерство оборони Польщі обладнало два мобільні пункти тестування сезонних працівників 3-за кордону.

У той же час значно більш складною є транспортна проблема. Якщо раніше мікроавтобуси перевозили з України по 7-10 працівників у конкретні місця сезонної роботи у Польщі, то наразі це майже неможливо. В уряді Польщі, як і в Україні, поки не дають однозначних прогнозів щодо відкриття кордонів i повного відновлення міжнародного сполучення. Утім, можливо, що це поступово буде відбуватися упродовж 2021 року, коли в Польщі завершиться черговий етап обмеження руху через кордон, запровадженого у зв'язку 3 пандемією COVID-19 [2]. 
Незважаючи на те, що уряд Польщі наразі активно заохочує українців приїжджати в РП на сезонні роботи, можна відзначити й іншу тенденцію. Вона виходить від польського уряду. Зокрема, у Раді міністрів РП намагаються підрахувати, чи зможуть в умовах можливої втрати українцями роботи у Польщі та їх повернення додому рядові поляки зайняти ніші на ринку праці, що звільнилися. У цьому контексті в Польщі вбачають один зі способів подолання проблеми зростаючого безробіття в умовах кризи.

Отже, упродовж коронавірусної епідемії громадяни України масово не виїхали з Польщі, але їх працевлаштування нині під сумнівом.

Статистика 2020 року демонструє, що кількість українців, які їдуть на заробітки у Польщу, практично дорівнює кількості тих, хто повертається додому. Уряд Польщі, з одного боку, прагне, щоб трудові мігранти з України масово приїжджали на сезонні роботи зі збору врожаю в Польщу, а з іншого - у РП усе частіше звучать думки про те, що в період кризи українців повинні замінити поляки.

Доцільно розглянути перспективи працевлаштування українців у Польщі у більш довгостроковій перспективі. Можна спробувати проаналізувати їх на основі експертних прогнозів, які, однак, динамічно міняються. За останніми оцінками польських економістів, ВВП країни в 2020 році скоротився на $3 \%$, а у 2021 р. його динаміка знаходитиметься на нульовому рівні. Рецесія спостерігається у ключових галузях, де працевлаштовано багато українців. Зокрема, у будівництві кількість публічних замовлень у 2020 році у порівнянні із 2019 р. знизилося на $30 \%$. Це може вплинути на працевлаштування українців, яких у цьому сегменті працює приблизно $15 \%$ [2].

Навряд чи польська влада зважиться на більшу відкритість у питанні надання дозволів на тимчасове або постійне проживання в країні. Найближчим часом на перше місце може вийти протекціонізм і бажання захистити польського працівника за рахунок іноземного. А далі все буде залежати від того, наскільки розтягнеться період виходу із кризи.

За переконанням експертів, наслідки кризи будуть відчуватися не тільки в 2021 році, але й у 2022 р. Скорочення грошових переказів 3 Польщі в Україну через наслідки пандемії може скласти 30\%. В еквіваленті це приблизно складе суму в 4 млрд доларів. Усе це стане наслідками втрати постійної роботи, зміни місця або умов праці, повернення українців додому в сукупності всіх цих факторів.

Розглянемо наслідки кризи власне для українського ринку праці. Рівень безробіття в Україні почав рости у квітні 2020 p, із запровадженням жорсткого карантину. У березні минулого року офіційно 126 
зареєстрованих безробітних в Україні було 349 тис. осіб, але у квітні цей показник сягнув 457 тис., У травні - 511 тисяч, а в червні 517 тисяч осіб. І тільки 3 липня 2020 р. почалося зниження цієї цифри до 506 тисяч, і в серпні - до 474 тисяч [1].

За даними Державного центру зайнятості, станом на кінець серпня 2020 року із початку карантину в Україні статус безробітного одержали майже 432 тис. осіб. На 20 листопада 2020 р. статус безробітного мали майже 488 тисяч українців (порівняно 3276 тисячами на цю же дату позаминулого року). На початку вересня 2020 р. кількість нових зареєстрованих безробітних у центрах зайнятості перестало зростати [1].

Ріст безробіття й зменшення зарплат не $є$ єдиними ознаками «карантинного» ринку праці. Можна виділити кілька ключових тенденцій, «підсвічених» коронакризою $[3,4]$ :

\section{Швидка зміна пріоритетів і нерівномірність}

Коли в одних сферах число вакансій знизилося більше ніж у 2 рази, в інших вона виростала втричі. I у межах однієї сфери за весну й літо 2020 р. можна було спостерігати то злети, то падіння числа пропозицій про роботу.

Різке збільшення конкуренції на ринку праичі

За останні місяці на одну вакансію стало припадати у 2-3 рази більше резюме, ніж це було наприкінці 2019 р. або на початку 2020 р. Така висока активність зі сторони здобувачів не завжди пов'язана тільки $з$ дефіцитом вакансій [4].

Оптимізація ц̌ висока конкуренція, а також максимальна оптимізаиія витрат

Головне питання, яке зараз ставить собі бізнес - наскільки потрібні ті або інші люди й функції. Якщо у 2019 р. компанії у сфері будівництва й архітектури входили у перелік активних, то сьогодні вони поступилися підприємствам, що займаються логістикою й транспортними послугами. Але незважаючи на загальний спад активності на ринку праці, компанії зі сфери роздрібної й оптової торгівлі, а також виробництва, залишаються активними роботодавцями другий рік поспіль [5].

Таким чином, коронавірусна інфекція спричинила досить жорстку кризу на ринках праці Польщі й України. Попри це, активне прагнення українців виїхати на заробітки до Польщі, практично не знизилося порівняно з 2019 роком. 


\section{Література:}

1. Уменьшились число предложений и средняя зарплата. Как пандемия COVID-19 изменила рынок труда в Украине URL: https://trans.info/ru/umenshilis-chislo-predlozheniy-i-srednyaya-zarplatakak-pandemiya-covid-19-izmenila-ryinok-truda-v-ukraine-201983.

2. Польский рынок труда: Есть ли там место украинцам в период коронакризиса и после? URL: https://www.ukrinform.ru/rubricworld/3033544-polskij-rynok-truda-est-li-tam-mesto-ukraincam-v-periodkoronakrizisa-i-posle.html

3. Вишневський В. П., Гаркушенко О. М., Князєв С. І. та ін. (2020). Цифровізація економіки України: трансформаційний потенціал: за ред. В. П. Вишневського та С. І. Князєва. Київ: ІЕП НАН України, 2020. $188 \mathrm{c}$.

4. Кулицький С. Український ринок праці під впливом пандемії COVID-19: стан та оцінка перспектив розвитку. Україна: подї̈, факти, коментарі. 2020. № 12. С. 43-57.

5. Лавриненко Л. М. Ринок праці на карантині та професії, які будуть затребувані після пандемії COVID-19. International scientific ejournal. 2020. № 9. URL: https://www.ukrlogos.in.ua/10.11232-26634139.09.13. 